\title{
О новой энергетической идеологии в пространственном развитии территорий: инновационное совершенствование отраслей ТЭК в урбоэ- кологическом территориальном развитии
}

\author{
Э.В.Сарнацкий, ЦНИИП Минстроя России, Москва
}

Инновационное совершенствование отраслей ТЭК в урбоэкологическом территориальном развитии рассматривается специалистами в области энергетики как новая энергетическая идеология. Основами развития принимается синтез трёх «Э»: экономика, экология, энергетика как факторов здоровья планеты Земля.

Энергетика - мотор экономики, развития и безопасности общества и государства: состояние и развитие промышленности, АПК, внешнеторговой политики, защиты природы (здесь некая амбивалентность). Эпоха углеводородов предоставляет открытые возможности для развития новых технологий. Как бы не менялись или не трансформировались взгляды и суждения о дальнем и недальнем нашем «завтра», максима «мир будет электрическим, экологическим и цифровым» уже наступает.

При этом постулат «Энергетика = физика + экономика» определяет направленность и сущность энергетической политики в территориальном планировании.

В материале статьи проводится сквозной анализ: от первичных энергоресурсов (их наличия и конечности потребления) до увязки схем тепло- и электроснабжения (нужно исходить из нашей российской климатической особенности - нам нужно две-три единицы тепла на единицу электроэнергии) и газо- и водоснабжения плюс энергосбережение - всё это вместе даёт колоссальные эффекты развития - от избавления от излишней мощности стареющих источников до создания новых и реконструкции целесообразных (стоимостные преимущества), до использования в ряде случаев вторичных, возобновляемых энергоресурсов и распределённых источников. Рассмотрен вариант создания Глобального энергетического объединения (ГЭО).

Совершенно необходимо возрождение отраслевой науки и энергомашиностроения; цифровизация, «смарт грид», энергосбережение.

Ключевые слова: первичные энергоресурсы, урбоэкология, низкоуглеродное развитие, возобновляемые источники энергии, централизованная и распределённая энергетика, энергоаккумуляторы, энергосбережение, «умные сети», цифровизация, Глобальное энергетическое объединение.

On the New Energy Ideology in the Spatial Development of Territories: Innovative Improvement of the Fuel and Energy Sector in Urban-Ecological Territorial Development

E.V. Sarnatskij, TSNIIP Minstroya of Russia, Moscow

Innovative improvement of the fuel and energy sector in urban ecological development is considered by experts in the field of energy as a new energy ideology. The fundamentals of development accept the synthesis of three "E": economy, ecology, energy as factors of the health of the planet Earth. Energy is the engine of the economy, development and security of society and the state: the state and development of industry, agriculture, foreign trade policy, protection of nature (here there is some ambivalence). The era of hydrocarbons provides open opportunities for the development of new technologies. No matter how transformed or transformed the views and judgments of ourlong-distance and near-distant "tomorrow", the maxim "the world will be electric, ecological and digital" is already coming. At the same time, the postulate "Energy = physics + economy" determines the direction and essence of energy policy in territorial planning. The article provides an endto-end analysis: from primary energy resources (their availability and consumption) tolinking the heat and power supply schemes (we must proceed from our Russian climatic peculiarity - we need two or three units of heat per unit of electricity) and gas and water supply plus energy saving - all this together gives colossal effects of development - from getting rid of the excessive power of aging sources to creating new and reconstructing coherent (cost advantages) to using in some cases secondary, renewable energy resources and distributed sources.

The revival of industrial science and power engineering is absolutely necessary; digitalization, smart grid, energy saving.

Keywords: primary energy resources, urban ecology, low carbon development, renewable energy sources, centralized and distributed energy, energy storage, energy saving, "smart grids", digitalization, Global Energy Association.

На долю ТЭКа приходится около 22\% ВВП страны, почти $60 \%$ экспорта и $40 \%$ дохода федерального бюджета. В условиях сложной рыночной конъюнктуры последних лет и искусственных внешних ограничений российский ТЭК сумел эффективно ответить на стоящие перед ним вызовы.

Ещё в октябре 2017 году в рамках Российской энергетической недели прошёл VI саммит «Глобальная энергия». Мероприятие собрало экспертов из четырёх стран, включая Россию, для полемики на тему «Формирование синтеза трёх “Э”» (экономики, экологии и энергетики) как фактора здоровья планеты Земля: эпоха углеводородов - открытые возможности для развития новых технологий». Как бы не менялись или не трансформировались взгляды и суждения о дальнем и недальнем нашем «завтра», максима «мир будет электрическим, экологическим и цифровым» уже наступает. 
Энергия не может рассматриваться как самоцель, некое самоценное благо; в дополнение к природным факторам наличия и проявления энергии человек использует свои возможности для создания (преобразования) различных видов энергии для своих нужд как универсального средства для обеспечения человечества: приемлемых параметров искусственно созданной среды обитания, высокой производительности труда при создании и движении товаров и услуг, возможной мобильности и коммуникаций, наконец - для познания мира. Количеством, качеством и разнообразием благ, получаемых с помощью энергии, определяется уровень развития общества. Энергия не исчезает и не возникает вновь - она переходит из одного вида в другой.

Кардинальные изменения мировой энергетической системы требуют новых технологий добычи, переработки и хранения энергетических ресурсов одновременно со сменой философии их потребления. Развитие подобных технологий - это не только решение экологических проблем, но и новые стимулы для глобальной экономики,

Значительный рост численности населения и его потребностей (основные из которых - вода и энергия), достаточно интенсивное истощение природных ресурсов, ухудшение (или непредсказуемая волатильность) климата, увеличение количества мировых энергоёмких промышленных центров и распределённых энергопотребностей влекут за собой новые вызовы и ставят новые непростые задачи для мирового энергетического сектора. Спрос на энергоресурсы будет расти, принципиально важно принять решительные (в определённой степени нетрадиционные) меры уже сегодня.

Суммарная мощность всех электростанций мира на сегодня превышает шесть тераватт. Однако коэффициент её использования - менее половины. Это связано с необходимостью резерва (как правило - не менее 20\%), но зависит также от дисбаланса электрической мощности и присоединённой нагрузки, режима потребления, смены времени суток, от потерь в сетях, аварий на генерирующем, трансформаторном и сетевом оборудовании и т.п. Повышение коэффициента использования установленной мощности (КИУМ) - постоянная забота энергетиков. Серьёзным изъяном является недостаточная связь между источниками генерации и их сетями с аналогичными факторами в других ближних и дальних энергосистемах. Установленная мощность электростанций в России - около 240 ГВт. Пиковое потребление электроэнергии от всей системы в РФ - 160 ГВт (сюда следует добавлять 20\% (32 ГВт) потребного резерва. Что собой представляют эти «лишние» 50 ГВт и откуда они возникли и что с ними делать - вопрос-вопросов!

В профессиональной среде и в кругах, принимающих стратегические и программные решения, возникает необходимость создания «нового ГОЭЛРО».

В недалёком прошлом «псевдоглавный энергетик России» А. Чубайс по случаю Энергетического форума-2018 разразился такой филиппикой: «Нужно создать мощный кластер из генерации, науки, промышленности и образования. Это должен быть самовоспроизводимый, сбалансированный кластер». Трудно возразить этому утверждению, особенно в части самовоспроизводимости и сбалансированности.

Неминуемый масштабный переход от традиционного способа генерации, распределения и управления энергоресурсами к новой цифровой энергосистеме будущего - один из главных трендов в сфере энергетики. Технологии искусственного интеллекта, машинного обучения, интернета вещей, блокчейна, больших данных и аддитивного производства способны ответить на глобальные вызовы энергетической отрасли и задать стандарты нового этапа технологического развития.

Следует помнить определения академика В. Фортова о том, что энергетика - консервативный и инерционный вид экономики, а любой способ генерации энергии наносит ущерб экологии. Он неоднократно повторял за академиком М. Стыриковичем, как мантру: «Энергетика = физика + экономика».

Известному «Экономика (здесь - энергетика) vs экология» могут противостоять только конвергенционные возможности. Отсюда стратегические устремления к низкоуглеродной энергетике.

Эмиссия углерода за счёт сжигания ископаемого топлива на территории России в 2000 году составила 420 Мт углерода, вырубка лесов - 40 Мт, лесные пожары - 35 Мт и эрозия почвы - 70 Мт, а суммарная эмиссия в результате хозяйственной деятельности - 565 Мт. В результате доля России в глобальной эмиссии углерода с учётом всех видов хозяйственной деятельности равнялась $6 \%$ от мировой.

Определённая неспешность в нашем отношении к Парижскому соглашению [не отрицая такового, но откладывая его ратификацию (в США провозглашён отказ от соглашения для спасения промышленности от излишних обременений; там даже генерация на основе угля реанимируется)] определила необходимость разработки у нас к декабрю 2019 года «Стратегии низкоуглеродного развития до 2050 года». Как бы то ни было, какими бы премудростями футурологи нас не потчевали, остаётся верной максима: «Мир будет электрическим, экологическим и цифровым».

\section{О роли топливно-энергетического комплекса в экономике}

Энергетика - мотор экономики, развития и безопасности общества и государства: состояние и развитие промышленности, АПК, внешнеторговой политики, защиты природы (здесь некая амбивалентность).

Необходимо оценивать ряд сравнительных показателей: нефтяная и газовая промышленность - самый производительный из крупных секторов: здесь выручка (проще говоря - производительность) составляет 18,5 млн рублей на работника. 21,3 трлн рублей совокупной выручки (30\% от выручки по всей стране) приходится на девять нефтегазовых компаний, при этом 59\% доходы предприятий, находящихся под контролем государства.

По данным журнала «Эксперт» (№ 43 от 28.10.2018) в 2007 году в нефтяной и нефтегазовой отрасли было занято 1,08 млн человек (Газпром - 470 тыс., Роснефть - 302 тыс., «ЛУКОЙЛ» 103,6 тысяч. 
Чтобы это аргументированно продолжить, следует дать абрисно картину экономики в нашей стране в сравнении с общемировыми показателями, не впадая в крайность суждений. Всё это следует рассматривать в общемировых тенденциях деглобализации экономики при глобальных тенденцияхтехнологического развития (во многом это последнее относится к энергетике). В 2017 году российская экономика после двух лет рецессии перешла к восстановительной стадии роста. По итогам прошлого года рост экономики составил 1,5\%, что значительно оптимистичнее первоначальныхпрогнозов (0,6\%). Удержание бюджетного профицита, строгое следование бюджетному правилу, масштабная скупка валюты, увеличение налогового бремени - все эти действия обретают смысл, если признать, что сейчас наиглавнейшая задача властей - создание финансовой подушки безопасности.

Рецессионный период сменился некоторым подъёмом, который не даст значительного рывка в 2019 году. Достижение национальной цели, установленной в майском указе президента - «вхождение страны в число пяти крупнейших экономик мира, обеспечения темпов экономического роста выше мировых при сохранении макроэкономической стабильности, в том числе инфляции науровне, не превышающем 4\%» - откладывается за пределы 2020 года. По прогнозу МЭР в будущем году нас ждёт ощутимое замедление роста - до 1,3\% с 1,8\%. По предварительной оценке Минфина, бюджетный профицит составил в прошлом году более 2,7 трлн рублей. «Весь профицит полностью был направлен на покупку валюты, более того, ещё 1,47 трлн рублей было отправлено на покупку валюты за счёт других источников. На 1 января 2019 года в ФНБ находилось немногим больше 4 трлн рублей, или 3,8\% ВВП РФ. По заключению Счётной палаты, на конец 2021 года объём ФНБ должен составить 14,3 трлн рублей, или 12,1\% ВВП. Расходы бюджета в 2018-ом составили беспрецедентно низкие 16,4\% ВВП, практически не изменившись по сравнению спредыдущим годом в номинальном выражении. Ещё в 2014-2016 годах этот показатель находился на уровне $19-20 \%$ ВВП.

В очередном обзоре мировой экономики «World Economic Outlook» МВФ прогнозирует сокращение в ближайшие шесть лет доли России в мировой экономике. Рассчитывать на вхождение РФ в пятёрку крупнейших экономик в таких обстоятельствахуже не приходится. В этом обзоре МВФ для России показан некоторый слабенький позитив: стране предсказывают ускорение экономического роста на десятые доли процента (правда, не принимая во внимание вероятные новые антироссийские санкции). Надежде выполнить президентский указ может способствовать ожидаемое торможение мировой экономики. Это некий вариант самообмана - в цифрах сравнения, но не по существу. Определённую динамику обнаруживаем при оценке в рейтинге конкурентоспособности экономики (Global Competitiveness Index, GCI) Всемирного экономического форума (WEF): «Россия поднялась с 45 на 43 место рейтинга, - результат макроэкономической стабильности: ВВП умеренно растёт, инфляция значительно снизилась, госдолг остаётся низким», - говорится в совместном сообщении WEF, Евразийского института конкурентоспособности и консалтинговой компании «Strategy Partners».
Рост общемирового ВВП в 2018 и 2019 годах, согласно обновлённому прогнозу МВФ, достигнет только 3,7\%, а не 3,9\%, как ожидалось ранее. Снижение связано в первую очередь с такими факторами, как введение США и Китаем (частично с ЕС) взаимных импортных пошлин, санкции против России, Ирана, Венесуэлы, отказ от ряда основополагающих соглашений (Парижского, по Ирану с КНДР и др.). Сюда же следует отнести как результирующий фактор ослабление показателей стран еврозоны, Японии и Британии, а также повышение процентных ставок, которое оказывает давление на ряд развивающихся экономик, в частности на Аргентину, Бразилию, Турцию и ЮАР, провоцируя отток капитала.

При всём этом график погашения внешнего долга по данным центра развития ВШЭ выглядит вполне позитивно.

Тем не менее материальный рост экономики налицо, фактор самообеспеченности сыграл в этом значительную роль при всех ограничениях (экономико-политических). Сложная ситуация в строительстве имеет рецепты выздоровления в виде ряда госпограмм.

Важность системного подхода и внедрения технологических инноваций в базовой энергетике отметил на Международном форуме «Российская энергетическая неделя» председатель Наблюдательного совета ассоциации «Глобальная энергия» Александр Шохин (Россия), президент РСПП: «В нашей стране добывающий сектор значительно отстаёт по инновационности от обрабатывающего. Считаю, что привнесение новых технологий в разведку и добычу традиционного сырья, которое происходит, в том числе, с помощью иностранных инвесторов - это хороший знак. Поступательное развитие всех видов энергетики - то, что

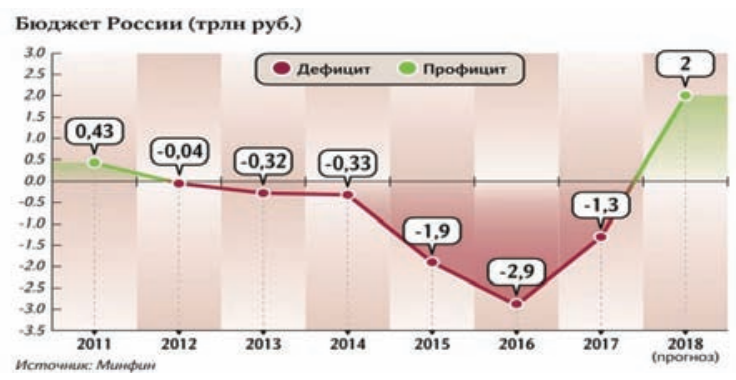

Волатильность бюджета России (трлн рублей) (источник: https://rosinformmburo.ru/2018/10/01/бюджет-2019-2021часть-і-два-триллиона/)

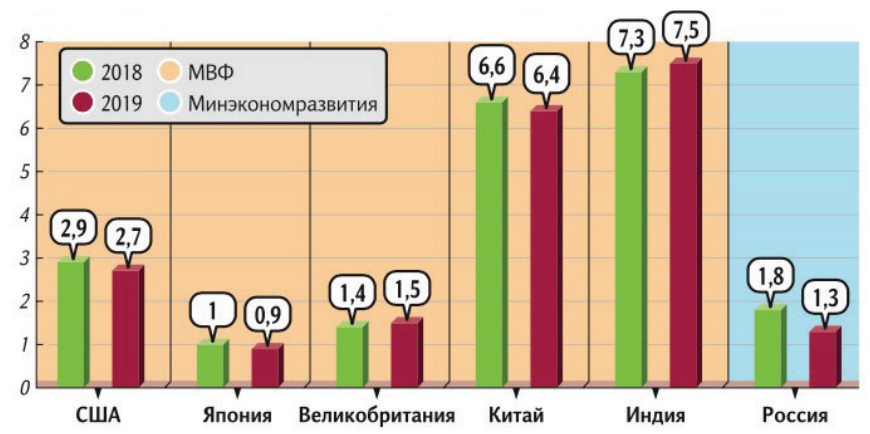

Прогноз развития экономик (в процентах) (источник: https://iz.ru/795273/inna-grigoreva/mirovoi-ekonomike-grozitzamedlenie-tempy-ee-rosta-sniziatsia-do-32) 
нам необходимо, в этом заключается системный подход. Только в таком случае мы будем готовы к любому резкому изменению топливно-энергетического баланса».

\section{Энергоресурсы: первичные и преобразованные}

Солнце является главным (единственным?) источником энергии на планете Земля. Ресурсы солнечной энергии огромны

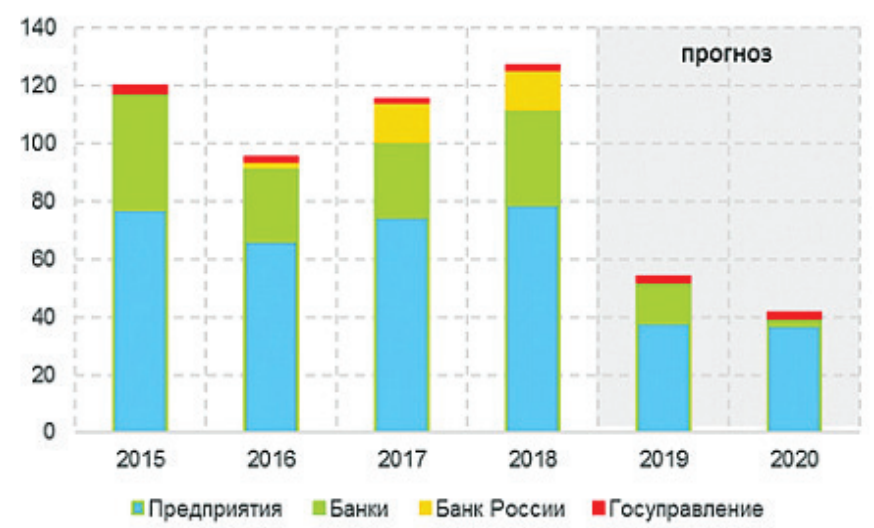

График погашения внешнего долга РФ (млрд долл.) (источник: http://www.ng.ru/economics/2018-10-30/1_7343_dolg.html)

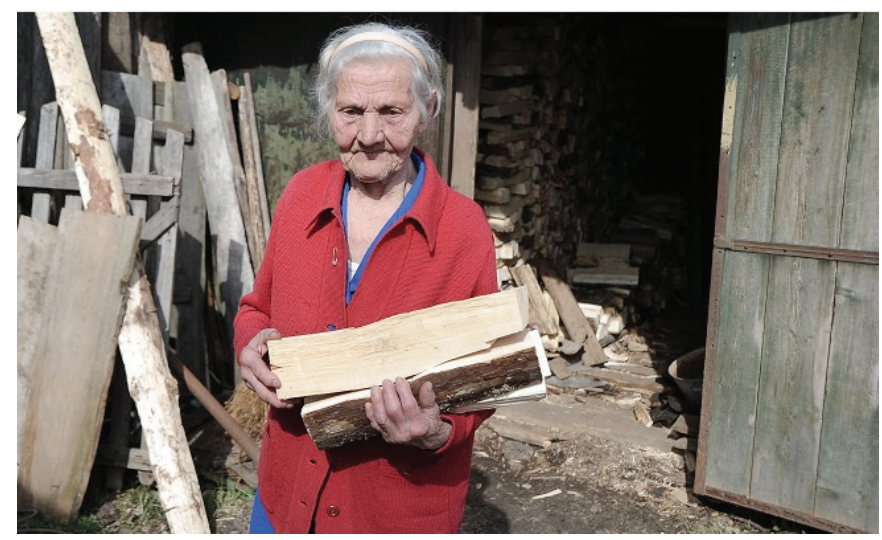

Самый архаичный из первичных источников энергии (источник: http://militariorg.ucoz.ru/_pu/863/48022042.png)

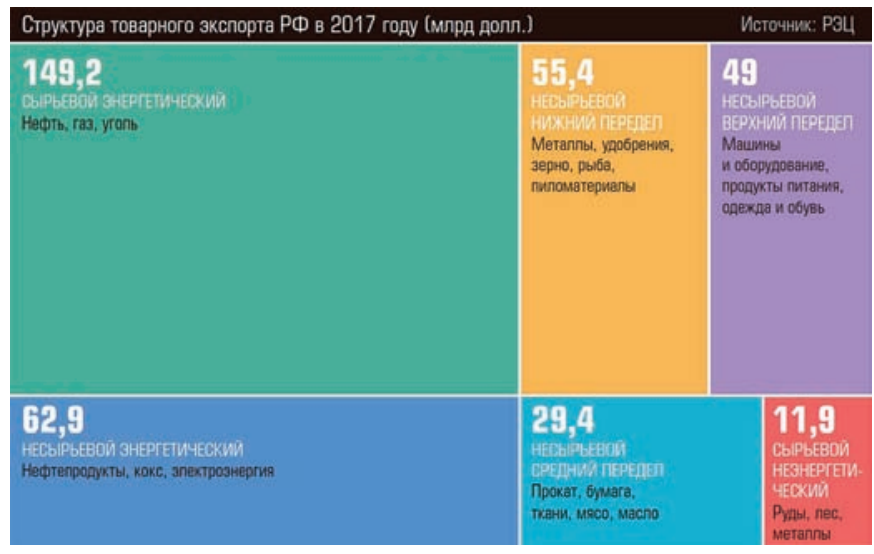

Структура товарного экспорта в 2017 году (источник: https://pbs.twimg.com/media/Dn2Ew9IWkAALDf1.jpg) и доступны практически каждой стране. Количество солнечной энергии, поступающей на территорию России в течение недели, превышает энергию всех российских запасов нефти, газа, угля и урана. В России и Европе доля опосредованно преобразованной солнечной энергии в виде биомассы и гидроэнергии составляет 6\% в общем производстве энергии, в развивающихся странах - 80\%.

За период с 1900 по 1990 год общее потребление энергии в мире возросло с 21 ЭДж до 320 ЭДж, то есть в 15 раз, тогда как численность населения за тот же период увеличилась только в три раза. (ЭДж - эксаджоуль; 1 ЭДж = 1018 Дж или количеству тепла, получаемого при сгорании 27 млн кубометров сырой нефти). За период с 1999 по 2020 год ожидается более чем полуторакратный рост потребления энергии. Но, как сегодня, так и в 2020 году, доля органического топлива в энергетическом балансе мира составит $87 \%$.

По словам гендиректора «Центра энергоэффективности - XXI век», лауреата Нобелевской премии в составе межправительственной группы экспертов по изменению климата Игоря Башмакова, к 2050 в электроэнергетику мира ориентировочно будет вложено $\$ 950$ млрд. Выработка электроэнергии увеличится в 2,4 раза, а мощности - в четыре раза. Эту тенденцию учитывают в своих программах развития электроэнергетики многих стран мира. При этом, по словам эксперта, 85 стран планируют довести объём возобновляемых источников энергии в своих государствах до 50\%, а ещё 57 - до 100\%. Россия, как дал понять эксперт, в число этих стран не входит, а кроме того здесь низкие показатели по энергоэффективности.

Тем не менее следует принимать во внимание, что на Земле три миллиарда человек используют дрова, уголь и экскременты животных (кизяк и т.п.) для приготовления пищи и обогрева.

В порядке исторического сравнения: каждый двор в старой России сжигал на обогрев жилища и приготовление пищи, по разным оценкам, от 30 до 50 куб. м древесины в год. Дворов таких в России при Петре I насчитывалось 800 тыс.

В последние несколько лет мировая экономика демонстрирует ускорение темпов прироста потребления первичной энергии, причём этот показатель варьируется в зависимости от географических регионов, отдельных страновых и блоковых экономик, секторов хозяйства, а также видов энергоносителей. Разнообразие параметров глобального и региональных энергетических рынков обусловлено факторами политического, социально-экономического и научно-технического характера: обострением конкурентной борьбы за рынки сбыта со стороны нетто-поставщиков, когда используются методы и способы торгово-политические, информационные, дипломатические и даже военные. Со стороны неттоэкспортёров рефлекторное поведение разнопланово и зачастую непредсказуемо, хотя наблюдается следование здравому смыслу - пример ОПЕК и ОПЕК+, вероятность газового ОПЕК и т.д. Необходимость компенсировать рост производственных и транспортно-логистических издержек, важных для экспортёров и импортёров, оптимизизацию логистических возможностей и распределение 
энергоносителей (первичных и преобразованных) по каналам международной торговли, их локальное потребление - всё это требует и получает в разной мере и степени научное обеспечение и новые технологии.

Обращает на себя внимание сохраняющаяся тенденция снижения/стабилизации расхода энергии в развитых странах мира. В государствах - членах ОЭСР, темпы прироста рассматриваемого показателя составили 1,3\% (в 2009 и 2014 годах зафиксировано даже его сокращение на $5 \%$ и 0,9\% соответственно). Вне ОЭСР ситуация оставалась неоднородной. В конце второго десятилетия участники СНГ вышли в зону положительных значений, а устойчивый спрос в Азиатско-Тихоокеанском регионе по-прежнему оставался ключевым фактором развития мировой энергетики и торговли топливно-энергетическими товарами. Структура глобального потребления первичной энергии продолжала эволюционировать от нефти и угля к более экологически чистым видам.

Во всем мире предприниматели уже осознали, что экспорт - не просто способ увеличить свои доходы, но и возможность вывести бизнес на совершенно другой уровень, став частью глобального рынка. Потенциал роста экспорта товаров из России очень высокий - до 25 раз в ближайшие несколько лет. Исторически так сложилось, что главным наполнителем бюджета РФ является экспорт углеводородов. К нему следует добавить АПК, Рособоронпром; остальной экспорт продукции значителен, но несопоставим с главным.

Упоминаемый обзор МВФ утверждает относительно экономического роста в России: экономика страны вырастет в следующем году на 1,8\%. (прежняя оценка фонда составляла 1,5\% роста) при некотором ускорения инфляции: годовая инфляция в стране на конец текущего года составит 3,6\%, в будущем году ускорится рост цен и инфляция составит 5,1\%. Это отвечает прогнозу Центоробанка РФ. Доля РФ в мировой экономике по мнению экспертов МВФ снизится с 3,09\% в 2018 году до 2,8\% в 2023 году. МВФ декларируется сокращение доли России в мировой экономике в ближайшие шесть лет. Россия тем самым займёт седьмое место в этом списке, - прогнозируют отечественные эксперты. «Номинальный объем ВВП РФ к 2023 году будет составлять всего лишь 1,8 трлн долл. (в 2013 году было 2,3 трлн долл.), или 1,67\% от объёма мирового ВВП.

Краткий обзор первичных энергоресурсов справедливо начать с нефти - ключевого экономического индикатора.

Как наиболее перспективные направления развития нефтегазового сектора определены технологии увеличения нефтеотдачи и коэффициента извлечения нефти, освоения трудноизвлекаемых запасов нефти и шельфовых месторождений, своего рода «нефтяное устойчивое развитие» (sustainable development). По утверждению экспертов, сегодня на континентальном шельфе на карты нанесено только 10-12\% от всех перспективных углеводородных богатств (по данным последнего обзора-ежегодника компании ВP («British Petroleum»). При нынешних объёмах добычи данных запасов хватит чуть более чем на 25 лет.

По сравнению с ведущими нефтяными державами Россия имеет одно из худших соотношений запасов к добыче. Для сравнения: Ираку и Ирану нефти хватит на 90 лет, Нигерии - на 50, Саудовской Аравии - на 61 год, а Венесуэле - на 392 года. Всего же, по оценке Минэнерго, суммарные извлекаемые ресурсы российской Арктики оцениваются в 100 млрд тонн н.э. - 13 млрд тонн нефти и 87 трлн куб. м газа.

\section{Нефтяники — основные инвесторы в стране}

600 5000

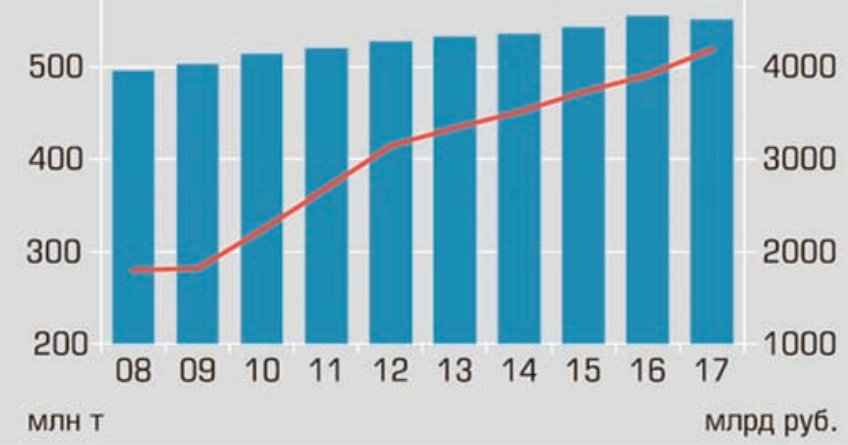

- Добыча нефти в стране

- Сумма инвестиций крупнейших нефтяных компаний (правая шкала)

a)

Производство бензина, дизельного График 1 топлива и авиакеросина в РФ

в последние годы стабилизировалось, а выпуск мазута резко сократился

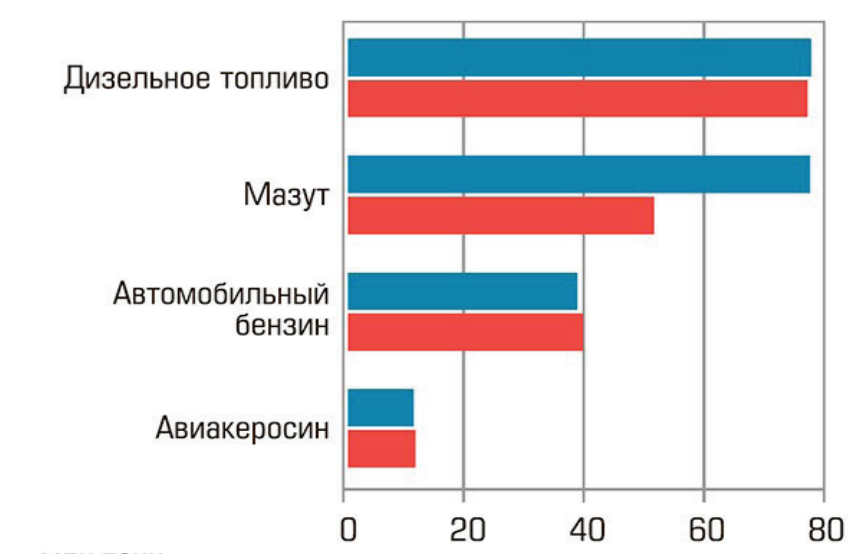

МлН ТОНн

\section{$2014-2017$}

\section{б)}

Производство нефтепродуктов [источник: a) https:// www.e-vid.ru/sites/default/files/article/inline-images/Heфтяники\%20-\%20основные\%20инвесторы\%20в\%20РФ. png; б) http://expert.ru/expert/2018/43/malyij---vpered/ media/319843/\#anchor-1] 
Производство газа, как наиболее чистого и ликвидного вида углеводородного топлива в мире, возросло в основном за счёт усилий России и Ирана на рекордные за последние десять лет 4\% (средний показатель - 2,6\% В год). Ведущими производителями данного энергоносителя являлись США (20\% суммарной добычи), Россия (17,3\%), Иран (6,1\%), Канада и Катар. Наряду с крупными экспортными проектами - «Сила Сибири», «Турецкий поток», «Северный поток-2» и проектами СПГ на Ямале и Сахалине, внутренняя газификация у нас всего $68 \%$ - самая низкая в Европе. Развитие газификации городов и посёлков усложняется проблемами безопасности газифицированных объектов, стоимостными показателями; газификация транспортных средств имеет схожие проблемы. Здесь нужны строгие инженерные решения и контроль и надзор в процессах эксплуатации устройств.

На 49-м Давосском форуме канцлер Меркель заявила: «Если мы отказываемся от угля, от атомной энергии, то должны честно признать, что потребность в природном газе возрастёт».

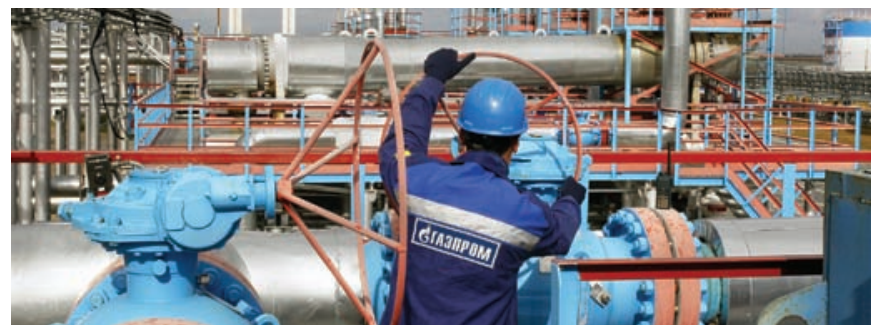

Газпром - национальное достояние (источник: https://saat. kg/wp-content/uploads/sites/6/2016/05/Gazprom.jpg)

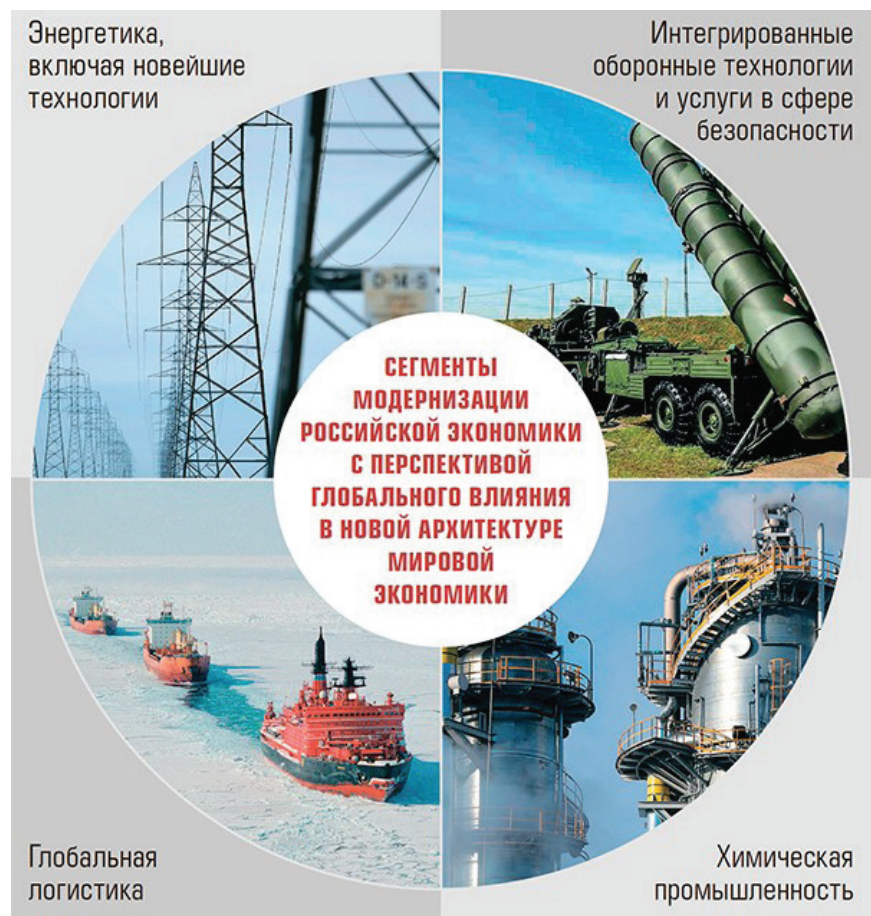

Сегменты мировой экономики и энергетика (источник: http://cd15893-wordpress.tw1.ru/wp-content/ uploads/2018/10/rossiya-na-fone-global-nogo-krizisaraspisanie-na-poslezavtra-13.jpg)
У нашей страны вторые в мире запасы угля после США (третья в мире - КНР). Этого твёрдого топлива (у РФ 200 млрд т), хватит на 500 лет добычи. Причём наиболее крупные российские угольные бассейны настолько богаты, что их можно разрабатывать тысячу лет. Во-вторых, как предполагается, через 15-20 лет мир может накрыть так называемая вторая угольная волна. Антрацит как самое дешёвое ископаемое топливо на новом этапе развития технологий вновь может стать движущей силой энергетики и будет активно замещать углеводороды. По расчётам экспертов Минэнерго, если мировой спрос продолжит рост, РФ будет зарабатывать на экспорте угля от 15 до 20 млрд долл. в год.

\section{Выводы и предложения}

Мир ждёт деглобализация, рецессия и рост национализма, а Россию - кризис либерализма. Устоявшиеся экономические связи рушатся, торговые барьеры растут, а мир ждёт рецессия, - пришли к выводу участники Давосского форума-2018.

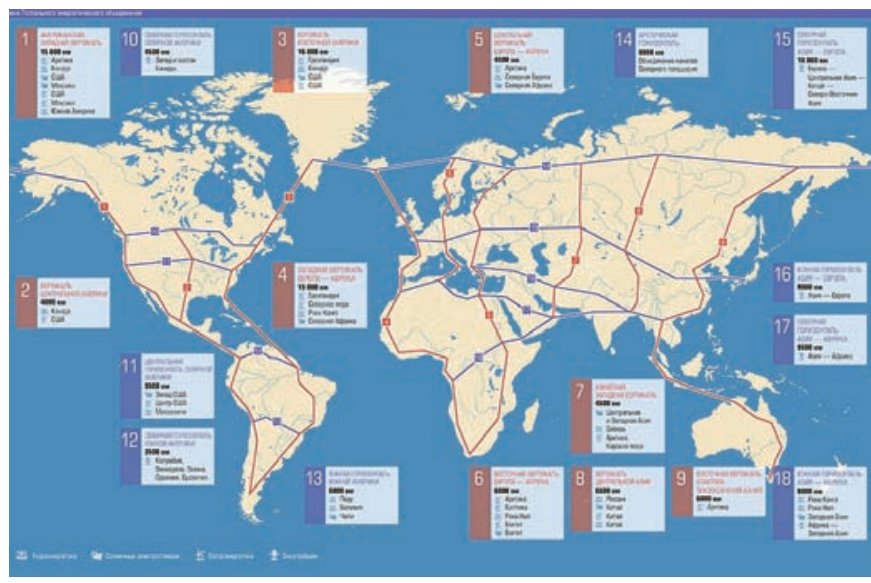

Предлагаемая карта сетей Глобального энергетического объединения (источник: http://www.energoinform.org/ news/2018/energy/images/svv-image-3.png)

\section{Supergrid, Smart Energy Belt}

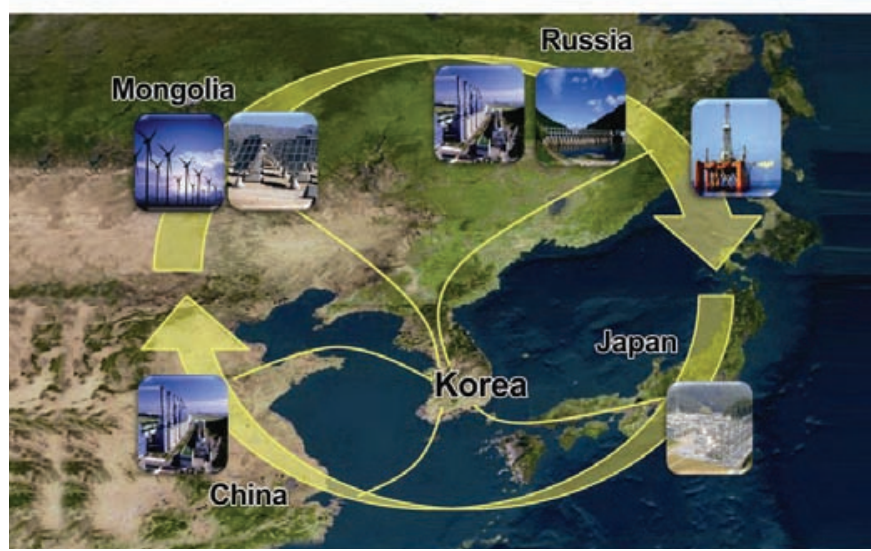

Вероятное энергокольцо Юго-Восточной Азии (источник: http://www.sibenergetic.ru/pub/article/8095/preview. jpg?636408135644445649) 
По словам главы МВФ Кристин Лагард, мировая экономика вырастет в 2019 году на 3,5\%, а в 2020-ом на 3,6\%, что ниже предыдущего прогноза на 0,2 и 0,1 п.п. соответственно. И главный вклад в это вносит Америка. Алексей Мордашов, председатель совета директоров «Северстали», отреагировал так: «Если даже на один день остановить глобализацию, мы не сможем прожить этот день. Электричества не будет».

Энергетическая трансформация будет не только способствовать появлению новых лидеров и игроков в области энергетики, изменению торговых отношений между государствами, но также поменяет положение стран на международной арене. Авторы доклада «Новый мир», эксперты Глобальной комиссии по геополитике в условиях энергетической трансформации утверждают, что изменения могут быть столь же существенными, как и те, которые возникли в результате перехода от биомассы к ископаемому топливу двести лет назад. Аднан Амин, член Международного комитета по присуждению премии «Глобальная энергия» утверждает: «Преимущества энергетической трансформации перевесят возможные вызовы, но только при ведении государством правильной политики и стратегии. Лидерам и политикам крайне необходимо предвидеть эти изменения, уметь управлять и ориентироваться в новой геополитической среде».

Наряду с крупными целями развития энергетики: возобновляемые источники, реакторы АЭС на быстрых нейтронах СПГ с системами логистики, умные электросети (smart grid), технологии вовлечения в энергоисточники газогидратов, водород, углехимия, развитие электротранспорта, цифровизация, - для условий нашей страны не менее важны распределённые энергоисточники, развитие газоснабжения поселений с гарантированными средствами энергобезопасности (14 мая 2019 года президентом В.В. Путиным утверждена новая редакция «Доктрины энергетической безопасности Российской Федерации»), сведение к минимуму перекрёстного субсидирования, тарифная политика в теплоснабжении и переход на «закрытые» схемы теплоснабжения, реальный статус альткотельных в тарифном регулировании, развитие энергосбережения и энергосервиса, восстановление энергомашиностроения по всей линейке мощностей, реанимация ведомственной науки. В качестве несколько отдалённой, но реальной глобальной цели международного энергетического сотрудничества рассматривается создание общемирового Глобального энергетического объединения (ГЭО) как двигателя перепрофилирования энергоресурсов и устойчивого развития. Его существо выражено формулой: «Умные электросети + электросети сверхвысокого напряжения + альтернативные источники энергии».

В качестве одного из первенцев ГЭО рассматривается Азиатское энергокольцо - Россия, Монголия, Китай, Япония, Корея.

\section{Лuтература}

1. Владимиров, В.В. Управление градостроительством и территориальным развитием / В.В. Владимиров. - М. : РААСН, 2000. - 89 c.
2. Путин, В.В. Прямая речь / В.В. Путин. В 3-х т. - М. : Звонница-МГ, 2016.

3. Сарнацкий, Э.В. «Градостроитель как системный интегратор когнитивного подхода к социально-экономическому обустройству территорий» / Э.В. Сарнацкий // Вопросы профессионализма в территориальном планировании : сборник материалов «Владимировских чтений». - Москва-Ростов-на- Дону, 2012.

4. Медоуз, Д. Пределы роста. 30 лет спустя / Д. Медоуз, Й. Рандерс, Д. Медоуз; Пер. с англ. - М. : Академкнига, 2007. - 342 с., ил.

5. Сарнацкий, Э.В. Выбранные места из дискуссий о градостроительной тематике / Э.В. Сарнацкий // Градостроительство. - 2011. - № 2.

6. Любовный, В.Я. Города России: альтернативы развития и управления / В.Я. Любовный. - М. : Экон-информ, 2013.

7. Вильнер, М.Я. Основы территориального планирования в Российской Федерации / М.Я. Вильнер. - М. : НП СРОСЭК СПОРТ, 2013.

8. Гутников, В.А. Государственная экспертиза инвестиционных проектов / В.А. Гутников. - М. : РУДН, 2013.

9. Флорида, Р. Креативный класс: люди, которые меняют будущее / Р. Флорида. - М. : Классика-XXI, 2011. - 430 с.

10. Гурова, Т. Братство в территориальных границах / Т. Гурова. - М. : Группа Эксперт, 2013.

11. Сарнацкий, Э.В. 0 демографических и миграционных вероятиях как важных факторах градостроительного развития в условиях глобализации / Э.В. Сарнацкий; РААСН // Фундаментальные исследования РААСН по научному обеспечению развития архитектуры, градостроительства и строительной отрасли Российской Федерации в 2014 году : сб. науч. тр. РААСН. - Москва-Курск, 2015.

12. Piketty, T. Capital in Twenty-First Century / T. Piketty. Cambridge, Massachusetts, London England 2014.

13. Сарнацкий, Э.В. «Камо грядеши» для Зеленограда - 2022 (Город, в котором хотелось бы жить) / Э.В. Сарнацкий // Вестник ВолгГАСУ. Серия: Строительство и архитектура. Вып. 31 (50). Ч. 1. «Города России. Проблемы проектирования и реализации». - Волгоград, 2013. - С. 175-179.

14. Примаков, Е.М. Россия. Надежды и тревоги / Е.М. Примаков. - М. : Центрполиграф, 2015.

15. Сарнацкий, Э.В. Инфраструктурные особенности в градостроительном развитии / Э.В. Сарнацкий // Градостроительство. - 2015. - № 5 (39).

16. Веллер, М. Накануне неизвестно чего / М. Веллер. - М. : ACT, 2016.

17. Сарнацкий, Э.В. Энигма урбанистической футурологии / Э.В. Сарнацкий // Градостроительство. - 2017. - № 3 (49).

18. Сарнацкий, Э.В. 0 полицентричности энергетической парадигмы в градостроительном развитии / Э.В. Сарнацкий, В.Я. Пейсахович // Фундаментальные, поисковые и прикладные исследования РААСН по научному обеспечению развития архитектуры, градостроительства и строительной отрасли Российской Федерации в 2016 году : сб. науч. тр. РААСН. Т. 1. - М. : ACB, 2017. - C. 448-457. 
19. Сарнацкий Э.В. Полицентричность парадигмы урбоэкологического пространственного развития / Э.В. Сарнацкий // Academia. Архитектура и строительство. -2018. - № 1. - С. 11-16.

20. Сарнацкий Э.В. Постучать по дереву / Э.В. Сарнацкий // Градостроительство. - 2018. - № 5.

\section{References}

1. Vladimirov V.V. Upravlenie gradostroitel'stvom i territorial'nym razvitiem [Management of urban planning and territorial development]. Moscow, publ. RAASN, 2000. 89 p.

2. Putin V.V. Pryamaya rech' [Direct speech]: v 3 t. Moscow, Zvonnitsa-MG, 2016.

3. Sarnatskij E.V. Gradostroitel' kak sistemnyj integrator kognitivnogo podhoda k sotsial'no-ekonomicheskomu obustrojstvu territorij [Urban planner as a system integrator of a cognitive approach to socio-economiclandscaping]. Voprosy professionalizma $v$ territorial'nom planirovanii: sbornik materialov «Vladimirovskih chtenij» [Questions of professionalism in territorial planning]. Moskva-Rostov-na-Donu, 2012.

4. Medouz D., Randers J., Medouz D. Predely rosta. 30 let spustya [Thelimits of growth. 30 yearslater] Moscow, Akademkniga, 2007. $342 \mathrm{p}$.

5. Sarnatskij E.V. Vybrannye mesta iz diskussij o gradostroitel'noj tematike [Selected places from discussions on urban issues]. Gradostroitel'stvo [Town planning], 2011. no. 2.

6. Lyubovnyj V.YA. Goroda Rossii: al'ternativy razvitiya i upravleniya [Cities of Russia: development and management alternatives]. Moscow, Ekon-inform, 2013.

7. Vil'ner M.YA. Osnovy territorial'nogo planirovaniya $v$ Rossijskoj Federatsii [Basics of territorial planning in the Russian Federation]. Moscow, NP SROSEK SPORT, 2013.

8. Gutnikov V.A. Gosudarstvennaya ekspertiza investitsionnyh proektov [State examination of investment projects]. Moscow, RUDN, 2013.

9. Florida R. Kreativnyj klass:lyudi, kotorye menyayut budushhee [Creative class: people who change the future]. Moscow, KlassikaXXI, 2011. $430 \mathrm{p}$.

10. Gurova T. Bratstvo v territorial'nyh granitsah [Brotherhood in territorial boundaries]. Moscow, Gruppa Ekspert, 2013.

11. Sarnatskij E.V. 0 demograficheskih i migratsionnyh veroyatiyah kak vazhnyh faktorah gradostroitel'nogo razvitiya $\checkmark$ usloviyah globalizatsii [0n demographic and migration likelihoods as important factors of urban development in the context of globalization]. Fundamental'nye issledovaniya RAASN po nauchnomu obespecheniyu razvitiya arhitektury, gradostroitel'stva i stroitel'noj otrasli Rossijskoj Federatsii v 2014 godu : sb. nauch. tr. RAASN [Fundamental research of the RAACS on the scientific support of the development of architecture, urban planning and the construction industry of the Russian Federation in 2014]. Moskva-Kursk, 2015.

12. Piketty T. Capital in Twenty-First Century. Cambridge, Massachusetts, London England, 2014.

13. Sarnatskij E.V. «Kamo gryadeshi» dlya Zelenograda - 2022 (Gorod v kotorom hotelos' by zhit') ["Kamo ridges" for Zelenograd - 2022 (City in which I would like to live)]. Vestnik VolgGASU. Seriya: Stroitel'stvo i arhitektura [Vestnik VolgGASU. Series: Building and Architecture]. Vyp. 31 (50). CH. 1. «Goroda Rossii. Problemy proektirovaniya i realizatsiì ["Cities of Russia. Design and Implementation Issues"]. Volgograd, 2013, pp. 175-179.

14. Primakov E.M. Rossiya. Nadezhdy i trevogi [Russia. Hopes and anxieties]. Moscow, TSentrpoligraf, 2015.

15. Sarnatskij E.V. Infrastrukturnye osobennosti $v$ gradostroitel'nom razvitii [Infrastructure features in urban development]. Gradostroitel'stvo [Town planning], 2015, no. (39).

16. Veller, M. Nakanune neizvestno chego [0n the Eve of the Unknown]. Moscow, AST, 2016.

17. Sarnatskij, E.V. Enigma urbanisticheskoj futurologii [Enigma Of urban futurology]. Gradostroitel'stvo [Town planning], 2017, no. 3 (49).

18. Sarnatskij E.V., Pejsahovich V.YA. 0 politsentrichnosti energeticheskoj paradigmy $v$ gradostroitel'nom razvitii [0n the polycentricity of the energy paradigm in urban development]. Fundamental'nye, poiskovye i prikladnye issledovaniya RAASN po nauchnomu obespecheniyu razvitiya arhitektury, gradostroitel'stva i stroitel'noj otrasli Rossijskoj Federatsii v 2016 godu : sb. nauch. tr. RAASN. T. 1. [Fundamental, research and applied research of the RAACS on the scientific support of the development of architecture, urban planning and the construction industry of the Russian Federation in 2016]. Moscow, ASV, 2017, pp. 448-457.

19. Sarnatskij E.V. Politsentrichnost' paradigmy urboekologicheskogo prostranstvennogo razvitiya [Polycentric paradigm of urban ecological spatial development]. Academia. Arhitektura istroitel'stvo [Academia. Architecture and Engineering]. 2018, no. 1, pp. 11-16.

20. Sarnatskij E.V. Postuchat' po derevu [Knock on wood]. Gradostroitel'stvo [Town planning], 2018, no 5.

Сарнацкий Эдуард Васильевич (Москва). Член-корреспондент РААСН. Старший научный сотрудник ФГБУ «ЦНИИП Минстроя России» (119331, Москва проспект Вернадского 29). Эл.почта: sarnat@bk,ru.

Sarnatsky Eduard Vasilievich (Moscow). Member-correspondent of the RAACS. Senior researcher of the Ministry of Construction and Housing and Communal Services of Russia (29 Vernadskogo avenue, Moscow, 119331. TSNIIP). E-mail: sarnat@bk.ru. 